\title{
Laminin Subunit Alpha-3
}

National Cancer Institute

\section{Source}

National Cancer Institute. Laminin Subunit Alpha-3. NCI Thesaurus. Code C137977.

Laminin subunit alpha-3 (3333 aa, $367 \mathrm{kDa}$ ) is encoded by the human LAMA3 gene. This protein is involved in both cell-matrix adhesion and the organization of the extracellular matrix. 